\title{
Electrochemical probe for polyamines detection in biological fluids
}

\author{
L. Scarciglia ${ }^{1}$, D. Compagnone ${ }^{2}$, G. Federici ${ }^{1}$ and G. Palleschi ${ }^{2}$ \\ ${ }^{1}$ Laboratorio di Biochimica Clinica, Ospedale Pediatrico "IRCCS Bambino Gesù", \\ Piazzale S. Onofrio $n^{\circ}$ 4, 00165 Rome, Italy \\ ${ }^{2}$ Dipartimento di Scienze e Tecnologie Chimiche, Universitá Tor Vergata, \\ via della Ricerca Scientifica, 00133 Rome, Italy
}

\begin{abstract}
The enzyme polyamine oxidase from maize has been purified and covalently immobilized onto polymeric supports to assemble a polyamine electrochemical biosensor. The enzyme has been used in conjunction with either an $\mathrm{O}_{2}$ or a $\mathrm{H}_{2} \mathrm{O}_{2}$ electrode. The analytical behaviour of this enzyme electrode has been studied with respect to sensitivity, selectivity, optimum $\mathrm{pH}$ and buffer, response time and lifetime. Recovery studies performed on urine samples demonstrated that the pol yamine biosensor developed can be successfully used to measure polyamines in biological fluids.
\end{abstract}

\section{Introduction}

Putrescine (put), spermidine (spd) and spermine (spm) belong to a class of compounds known as polyamines. Polyamines are low molecular weight molecules present in bacteria, plant and tissues and playing an important role in growth processes [1]. In fact, polyamines content increases during the synthesis of nucleic acids and proteins; high levels of polyamines in biological fluids have been also observed in case of cancer development [2]. For this reason, polyamines have been proposed as tumour marker [2,3]; the increase of polyamines in blood levels is well correlated with the amount in urine and this biological fluid has been suggested for cancer therapy monitoring [4,5]. 
Polyamine analysis is currently carried out using electrophoretic and chromatographic techniques [2,6-9]. The determination of polyamines via enzymatic analysis using the enzymes polyamine oxidase (PAO) and diamine oxidase (DAO) has been a goal to achieve in recent years. Electrochemical enzyme probes based on oxygen electrodes and the enzyme DAO have been realized $[10,11]$. The use of the enzyme polyamine oxidase (PAO) immobilised in reactors [12-14] or cross-linked with glutaraldehyde onto electrochemical probes [15] has been attempted and reported in the literature.

However, these probes showed low sensitivity for spermidine (spd) and spermine (spm). Our work consisted in the construction and assembling of a highly specific and sensitive amperometric biosensor for spermidine and spermine using the enzyme PAO purified from maize. This enzyme was covalently linked onto a commercially available Immobilon affinity membrane and the detection has been carried out using either $\mathrm{H}_{2} \mathrm{O}_{2}$ or $\mathrm{O}_{2}$ sensors. Analytical parameters such as enzyme immobilisation, optimum $\mathrm{pH}$ and buffer have been optimised and interferences minimised. A recovery study has been carried out in urine; the $\mathrm{O}_{2}$ based probe appears more suitable to the measurement of polyamines in biological fluids because of its interferencefree performance.

\section{Experimental}

\section{Apparatus}

The hydrogen peroxide probe was from Universal Sensors Inc. Metairie, LA, USA; the oxygen probe was from Instrumentation Laboratory S.p.a., Milano, Italy. The current signal was recorded with an Amperometric Biosensor Detector (ABD) from Universal Sensors Inc. connected with a Linseis Selb L6512 x-t recorder. Temperature was kept constant with a Haake (Berlin, Germany) thermostat connected to a double wall beaker.

\section{Materials}

Polyamine oxidase (PAO; EC 1.4.3.4), specific activity $32 \mathrm{U} / \mathrm{mg}$, was obtained from maize seeds grown for $8-10$ days on vermiculite in a dark room at $25^{\circ} \mathrm{C}$. The enzyme was purified following the procedure of Suzuki and Hirasawa $[16,17]$. The enzymatic activity was determined at $37{ }^{\circ} \mathrm{C}$ in $0.1 \mathrm{~mol} / \mathrm{L}$ phosphate buffer $\mathrm{pH} 7.0$ as reported by Padiglia et al. [18]. Spermidine, spermine, putrescine and all other reagents were from Sigma Chemical Co., St Louis, MO, USA. Kathon $\mathrm{CG}^{\circledR}$ was from Sinerga s.r.l., Pero, Milan, Italy.

The cellulose acetate membrane (nominal molecular weight cut-off $100 \mathrm{Da}$ ) was prepared in our laboratory as reported in the literature [19]. The teflon gas-permeable membrane was from AMEL, Milan, Italy and the polycarbonate membrane $(0.2 \mu \mathrm{m}$ porosity) was from Nuclepore, Pleasanton, CA, USA.

An Immobilon ${ }^{\mathrm{TM}}$ Affinity membrane from Millipore Co., Bedford, MA, USA and a nylon net $\left(60 \mathrm{mesh} / \mathrm{cm}^{2}, 100 \mu \mathrm{m}\right.$ thickness), obtained from a local shop, were used as support for the enzymatic mixture.

\section{Enzyme immobilisation procedure}

Two different membranes were used for the immobilisation of polyamine oxidase:

a) Immobilon ${ }^{\mathrm{TM}}$ affinity membrane (hydrophilic polyvinylidene difluoride) chemically derivatized to allow covalent protein immobilisation through the $\varepsilon$ - amino groups of lysines;

b) nylon net used only as physical support with glutaraldehyde as cross - linking agent.

$10 \mu \mathrm{L}$ of a solution containing $80 \mathrm{U} / \mathrm{mL}$ PAO were pipetted onto a $1 \mathrm{~cm}^{2}$ Immobilon membrane. The membrane was let to dry for 1 hour then washed with $\mathrm{KCl} 1 \mathrm{~mol} / \mathrm{L}$ and stored at $4{ }^{\circ} \mathrm{C}$ in citrate buffer $0.1 \mathrm{~mol} / \mathrm{L} \mathrm{pH} 5.5+0.1 \%$ kathon (w/v). Kathon was used as antibacterial agent.

The immobilisation of the enzyme on the nylon net was carried out as follows: $20 \mu \mathrm{l}$ of a solution containing $16 \mu \mathrm{L}$ of PAO $(1.28 \mathrm{U})$ and $4 \mu \mathrm{L}$ of glutaraldehyde $0.25 \%$ in $0.1 \mathrm{~mol} / \mathrm{L}$ phosphate buffer $\mathrm{pH} 7.0$, were pipetted onto the net and let to dry for 1 hour. The enzymatic membrane was then washed with $0.1 \mathrm{~mol} / \mathrm{L}$ glycine $\mathrm{pH} 8.0$ to remove the excess of unreacted glutaraldehyde and stored at $4{ }^{\circ} \mathrm{C}$ in citrate buffer $0.1 \mathrm{~mol} / \mathrm{L} \mathrm{pH} 5.5+0.1 \%$ kathon.

\section{Probe assembling}

The $\mathrm{H}_{2} \mathrm{O}_{2}$ biosensor was assembled by placing onto the platinum electrode the membranes in the following order: the cellulose acetate membrane to protect the electrode from electrochemical interferences, the enzyme membrane and the polycarbonate externally to protect the enzyme from large molecules and bacterial attacks. The membranes were then secured with an $\mathrm{O}$ - ring. $0.1 \mathrm{~mol} / \mathrm{L} \mathrm{KCl}$ was used as supporting electrolyte and the working electrode was polarised at $+650 \mathrm{mV}$ vs. $\mathrm{Ag} / \mathrm{AgCl}$.

The $\mathrm{O}_{2}$ sensor was assembled as already described replacing the cellulose acetate membrane with a Teflon gas-permeable membrane. The working electrode was polarised at $-700 \mathrm{mV}$ vs. $\mathrm{Ag} / \mathrm{AgCl}$.

\section{Results and discussion}

The reaction catalysed by the enzyme polyamine oxidase (PAO) from maize seeds is the following [20]:

$$
\text { 1) } \begin{gathered}
\mathrm{NH}_{2}\left(\mathrm{CH}_{2}\right)_{3} \mathrm{NH}-\left(\mathrm{CH}_{2}\right)_{4} \mathrm{NH}_{2}(\mathrm{spd})+\mathrm{O}_{2}+\mathrm{H}_{2} \mathrm{O} \\
\longrightarrow \mathrm{NH}_{2}\left(\mathrm{CH}_{2}\right)_{3} \mathrm{CHO}+\text { Dap }+\mathrm{H}_{2} \mathrm{O}_{2}
\end{gathered}
$$

$$
\text { 2) } \begin{gathered}
\mathrm{NH}_{2}\left(\mathrm{CH}_{2}\right)_{3} \mathrm{NH}-\left(\mathrm{CH}_{2}\right)_{4} \mathrm{NH}\left(\mathrm{CH}_{2}\right)_{3} \mathrm{NH}_{2}(\mathrm{spm})+\mathrm{O}_{2}+\mathrm{H}_{2} \mathrm{O} \\
\longrightarrow \mathrm{NH}_{2}\left(\mathrm{CH}_{2}\right)_{3} \mathrm{NH}\left(\mathrm{CH}_{2}\right)_{3} \mathrm{CHO}+\text { Dap }+\mathrm{H}_{2} \mathrm{O}_{2}
\end{gathered}
$$

$$
\text { Dap = diaminopropane. }
$$

An enzyme electrode can thus be realised by monitoring the $\mathrm{O}_{2}$ consumed or the $\mathrm{H}_{2} \mathrm{O}_{2}$ produced during the enzymatic reactions. 


\section{$\mathrm{H}_{2} \mathrm{O}_{2}$ probe}

The calibration curves for spermine and spermidine and for an equimolar solution of the two are reported in figure 1. These calibration curves have been attained using the two immobilisation procedures described in the Experimental section. Both the procedures gave good results and it was evident that the response was very similar for the two amines. This was confirmed by the response of the equimolar mixture of spermidine and spermine.

The biosensor response was linear in a wide range of concentration $\left(1 \times 10^{-6}-7 \times 10^{-4} \mathrm{~mol} / \mathrm{L}\right)$. Even though both the immobilisation procedures led to the same results the procedure based on the Immobilon membrane was selected because it was easier, needed lower amount of enzyme and resulted in a longer enzyme life-time $(100 \%$ of the response after 3 month storage in working buffer + kathon $0.1 \%$ ).

The effect of $\mathrm{pH}$ and buffer on the response of the PAO biosensor was studied in the $4.2-9.3$ range using phthalate buffer $(4.2-5.2)$, citrate buffer $(5.2-5.9)$, phosphate buffer $(5.6-7.4)$, and borax buffer $(8.0-9.3)$. The concentration of all the buffers used was $0.1 \mathrm{~mol} / \mathrm{L}$.

As shown in figure 2 the probe was able to perform the analysis of both the polyamines over a wide range of $\mathrm{pH}$. No significative change in sensitivity was observed with all the buffer tested in the $5.2-8.0 \mathrm{pH}$ range. Since it is advisable to use as a calibrator for the polyamine analysis an equimolar mixture of spermine and spermidine, citrate buffer, which gave the most similar response for both the amines (at $\mathrm{pH}$ 5.5) was selected for further experiments.

The response time of the probe was about two minutes. This time was calculated as the time necessary to reach $95 \%$ of the current steady state after injection of the standard into a solution consisting of citrate buffer $\mathrm{pH}$ 5.5. The concentration of the amine injected was $1 \times 10^{-4} \mathrm{~mol} / \mathrm{L}$.

The probe was stored at $4{ }^{\circ} \mathrm{C}$ in a $0.1 \mathrm{~mol} / \mathrm{L}$ citrate buffer solution pH $5.5+$ kathon $0.1 \%$ when not in use. After 45 days of continuous use (standard and urine samples) the probe maintained $100 \%$ of its initial activity.

The probe response to some substrates (amines and aminoacids) at a concentration $1 \times 10^{-4} \mathrm{~mol} / \mathrm{L}$ was evaluated to assess specificity of the immobilised enzyme. Immobilised PAO was highly selective for spermidine and spermine, giving no response for tryptamine, histamine, putrescine, cadaverine, ornithine, glutamine, arginine, lysine, tryptophan, tyrosine. Only tyramine gave a response of $9 \%$ compared with spermine. The relative standard deviation was $1.3 \%$ for a series of 5 measurements performed using a concentration of $5 \times 10^{-6} \mathrm{~mol} / \mathrm{L}$ and $4.3 \%$ using a concentration of $1 \times 10^{-4} \mathrm{~mol} / \mathrm{L}$. The $\mathrm{H}_{2} \mathrm{O}_{2}$ probe was then tested in a solution containing diluted urine (from 1:10 to 1:100 in working buffer). The matrix resulted to contain high concentration of electrochemical interferants which pass through the cellulose membrane giving a drift in the background current. This fact led us to abandon the $\mathrm{H}_{2} \mathrm{O}_{2}$ probe and our efforts concentrated in the use of the $\mathrm{O}_{2}$ probe.

\section{$\mathrm{O}_{2}$ probe}

Being the $\mathrm{O}_{2}$ probe response subject to oxygen fluctuations and temperature variation, samples and standards were aerated before measurements and all the measurements were
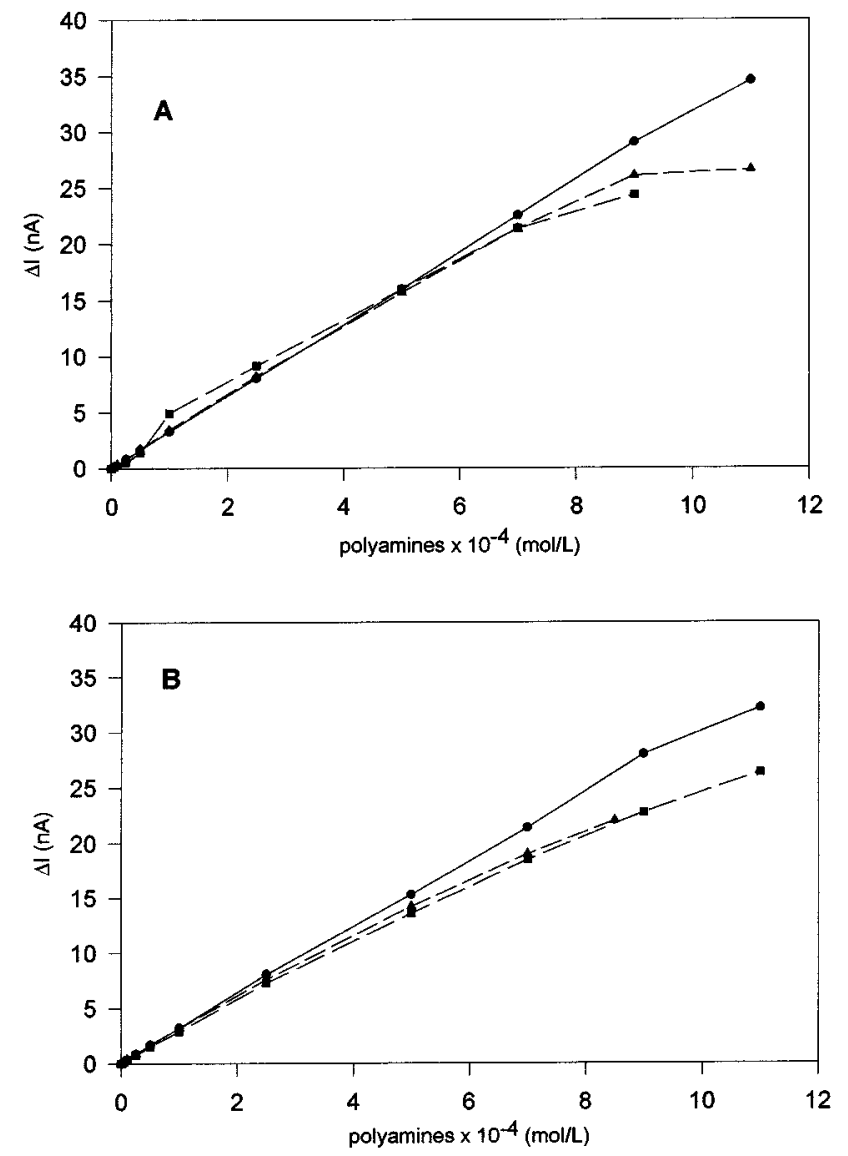

Fig. 1. Calibration curves for: $\operatorname{spm}(\square)$, spd $(\bullet)$ e $\operatorname{spm}+\operatorname{spd}(\Delta)$ using PAO immobilised with Immobilon AV (A) and BSA-glutaraldehyde (B).

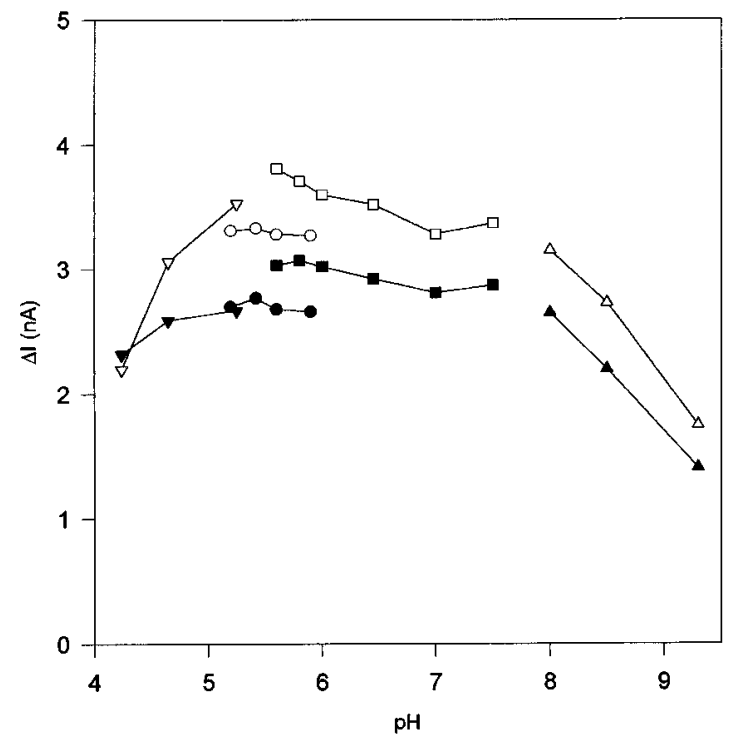

Fig. 2. $\mathrm{pH}$ profile of the $\mathrm{PAO}$ biosensor in the $4.2-9.3$ range for spm (bold) and spd (empty). $\mathrm{pH}=4.2-5.2$ phtalate buffer $(\mathbf{\nabla}, \nabla)$; 5.2 - 5.9 citrate buffer $(\bullet, O)$; $5.6-7.4$ phosphate buffer $(\mathbf{\square}, \square)$; $8.0-9.3$ borax buffer $(\boldsymbol{\Lambda}, \Delta)$. 
carried out in a double wall beaker thermostated at $25{ }^{\circ} \mathrm{C}$. Figure 3 shows a calibration curve of a mixture of spermidine and spermine measured in the $5 \times 10^{-6}-2 \times 10^{-4} \mathrm{~mol} / \mathrm{L}$ range. This narrower linearity range was expected because of the lower sensitivity of the $\mathrm{O}_{2}$ electrode versus the $\mathrm{H}_{2} \mathrm{O}_{2}$ electrode $\left(5 \times 10^{-6}-1 \times 10^{-4} \mathrm{~mol} / \mathrm{L}\right.$ for $\mathrm{O}_{2}, 1 \times 10^{-7}-1 \times$ $10^{-3} \mathrm{~mol} / \mathrm{L}$ for $\mathrm{H}_{2} \mathrm{O}_{2}$ ). The relative standard deviation was $3 \%$ for a series of 10 measurements performed using a concentration of $2.5 \times 10^{-5} \mathrm{~mol} / \mathrm{L}$ and $2 \%$ using a concentration of $1 \times 10^{-4} \mathrm{~mol} / \mathrm{L}$.

To assess the influence of the matrix onto the response of the developed PAO biosensor a recovery study was carried out. Standard solutions of a spm-spd mixture were added in a pool of urine samples diluted 1:10 to $1: 50$ in the working buffer. Results are reported in table I. A $100 \%$ recovery of the signal was obtained using a 1:50 dilution of the urine sample that would then be the recommended dilution for the analysis of polyamines with this probe. Recovery for more concentrated samples (1:10 and 1:20) was not satisfactory indicating a decrease in the working solution oxygen content caused by the sample.

\section{Inhibition study}

Free and acetylated polyamines content in urine has been shown to increase in the presence of some forms of cancer $[13,5,2]$. For this reason, all the current methods for the determination of polyamines include an acid hydrolysis pretreatment of the sample in order to have all the polyamines in the free form $[21,22]$. The effect of acetylspermine and acetylspermidine on the biosensor response was studied. Both the compounds resulted to decrease the response to spermine and spermidine. This effect is clear from the calibration curves for spermidine shown in figure 4 . The presence of acetylspermine in solution at concentrations of $10^{-5}-5 \times 10^{-5} \mathrm{~mol} / \mathrm{L}$ clearly influenced the sensitivity of the PAO biosensor. This inhibition effect can be explained by the analogy of the structure of the acetylated and free polyamines that compete for the site of the enzyme; this is confirmed by the restored initial activity for subsequent calibrations run without acetylspermine in solution. The inhibition by the acetylated forms was found to be a characteristic of the immobilised PAO enzyme. Using a diamine oxidase (DAO) biosensor previously developed in our laboratory [23], a current signal and the formation of a steadystate was observed for injections of acetylspermine in solution. This signal was about $30 \%$ of that measured for spermine; moreover, no inhibition of the spermine response was recorded.

Table I. Recovery study carried aut at different dilutions of a sample of urine.

\begin{tabular}{cccc}
\hline $\begin{array}{c}\text { spm }- \text { spd } \\
\text { mol/L }\end{array}$ & $\begin{array}{c}\text { Recovery } \\
\text { in urine dil. } 1: 10 \\
\%\end{array}$ & $\begin{array}{c}\text { Recovery } \\
\text { in urine dil. } 1: 20 \\
\%\end{array}$ & $\begin{array}{c}\text { Recovery } \\
\text { in }\end{array}$ \\
\hline $5 \times 10^{-6}$ & 28 & 71 & $\%$ \\
$1 \times 10^{-5}$ & 27 & 60 & 91 \\
$5 \times 10^{-5}$ & 65 & 84 & 94 \\
$1 \times 10^{-4}$ & 76 & 92 & 100 \\
$2 \times 10^{-4}$ & 86 & 95 & 96 \\
\hline
\end{tabular}

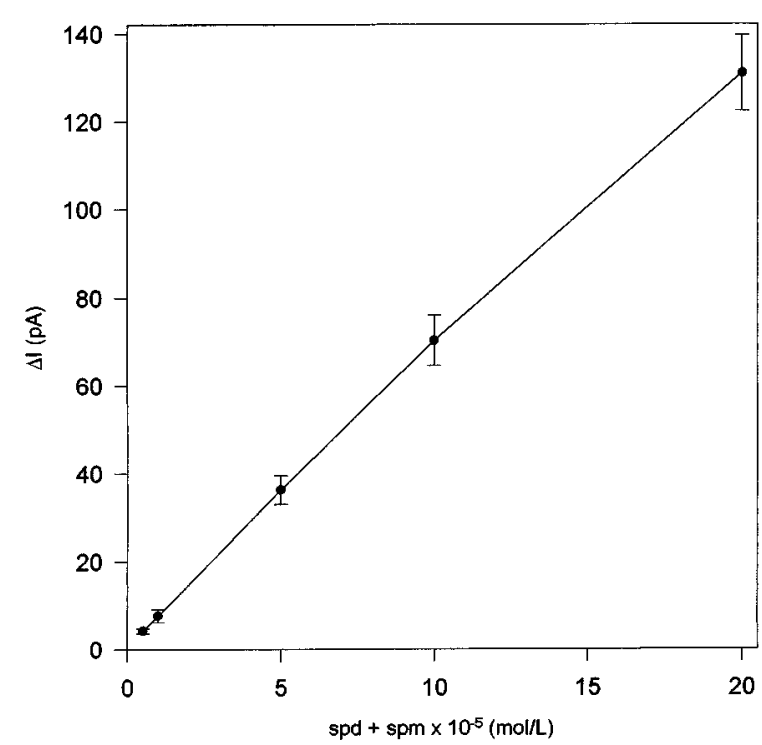

Fig. 3. Calibration curve for the $\mathrm{O}_{2}$ based probe.

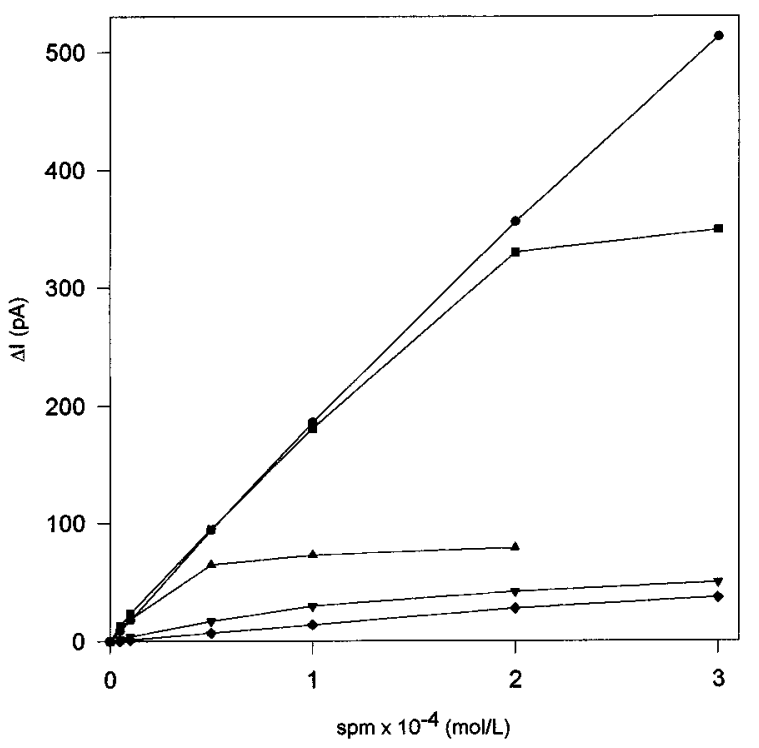

Fig. 4. Calibration curves for spm without acetylspermine $(\bullet)$ and with: $5 \times 10^{-6} \mathrm{~mol} / \mathrm{L}(\square), 1 \times 10^{-5} \mathrm{~mol} / \mathrm{L}(\Delta), 2 \times 10^{-5} \mathrm{~mol} / \mathrm{L}(\nabla)$ and $5 \times 10^{-5} \mathrm{~mol} / \mathrm{L}$ acetylspermine $(\bullet)$ in solution.

We can then conclude that in order to perform an accurate polyamine analysis with the PAO biosensor in urine samples it will be necessary an acid hydrolysis step as in the previously reported procedures.

\section{Acknowledgements}

Authors thank the MURST for financial support.

\section{References}

1. Tabor, H.; Tabor, C. W. Pharmacol Rev. 1964, 16, 245-300.

2. Lipton, A.; Sheehan, L. M.; Kessler, G. F. Cancer 1975, 35, 464-468. 
3. Russell, D. H. Clin. Chem. 1977, 23(1), 22-27.

4. Russell, D. H. Nature 1971, 233, 144.

5. Russell, D. H.; Levy, C. C.; Schimpff, S. C.; Hawk, I. A. Cancer Res. 1971, 31, 1555-1558.

6. Marton, L. J.; Lee, P. L. Y. Clin. Chem. 1975, 21, 1721.

7. Newton, N. C.; Ohno, K.; Abdel - Monem, M. M. J. Chromatogr. 1976, 124, 277.

8. Adler, H.; Margoes, M.; Snyder, L. R.; Spitzer, C. J. Chromatogr. 1977, 143, 125.

9. Perin, F.; Sadow, J. B.; Hixson, C.V. Anal. Biochem. 1979, 94, 431.

10. Karube, I.; Satoh, I.; Araki, K.; Suzuki, S. Enzyme Microb. Technol. 1980, 2, 117-120.

11. Toul, Z.; Macholan, L. Collection Czechoslov. Chem. Commun. 1975, 40, 2208-2217.

12. Kamei, S.; Ohkubo, A.; Yamanaka, M.; Okada, M.; Imahori, K. Jpn. J. Clin. Chem. 1984, 13, 66-73.

13. Hiramatsu, K.; Kamei, S.; Sagimoto, M.; Kinoshita, K.; Iwasaki, K.; Kawakita, M. J. Biochem. 1994, 115, 584-589.
14. Watanabe, N. Biom. Chromatogr. 1992, 6, 1-3.

15. Macholán, L.; Jílková, D. Collection Czechoslovak Chem. Commun. 1983, 48, 672-678.

16. Suzuki, Y.; Hirasawa, E. Phytochemistry 1973, 12, 2863.

17. Hirasawa, E.; Suzuki, Y. Phytochemistry 1975, 14, 99.

18. Padiglia, A.; Cogoni, A.; Floris, G. Phytochemistry 1991, 30, 3895-3897.

19. Mascini, M.; Mazzei, F.; Moscone, D.; Calabrese, G.; Massi Benedetti, M. Clin. Chem. 1987, 33, 591-593.

20. Federico, R.; Angelini, R. Biochemistry and Physiology of Polyamines in Plants, Slocum, R. D.; Flores, H. E. Eds., CRC press. Boca Roca (USA) 1991; Chapter 3.

21. Lipton, A.; Sheehan, L. M.; Kessler, G. F. Cancer 1975, 35, 464-468.

22. Russell, D. H.; Medina, V. J.; Snyder, S. H. J. Biol. Chem. 1970, 245(24), 6732-6738.

23. Draisci, R.; Volpe, G.; Lucentini, L.; Cecilia, A.; Federico, R.; Palleschi, G. Food Chem. (in press). 